\title{
The Comparison of Lexical Collocations in English Textbooks Used in Indonesia
}

\author{
Nur Ifadloh $^{1 \bowtie}$, Warsono Warsono ${ }^{2}$, Abdurrahman Faridi $^{2}$ \\ 1. STAI Rasyidiyah Khalidiyah (Rakha) Amuntai, Indonesia \\ 2. Universitas Negeri Semarang, Indonesia
}

\section{Article Info}

Article History:

Recived 09 April 2021

Accepted 06 July2021

Published 15

September 2021

Keywords:

Collocations, Lexical

Collocations,

Textbooks

Abstract

Teaching collocations becomes very important for ESL/EFL students to achieve language fluency since the students spend a great amount of time interacting with their textbooks. This study aims to investigate the comparison of lexical collocations used in two textbooks used regularly in senior high school level in Semarang namely Aim High Student's Book 1 and Bahasa Inggris Kelas X. This study applied descriptive qualitative method. The documentary method was used in collecting the data. The data were analyzed based on collocation theories proposed by Benson, et al. (1997) and Lea (2002). The result showed that there were three similarities found regarding the lexical collocation occurrence in all parts of the textbooks, the highest frequency of the lexical collocations occurrence in the exercise part of the textbooks, and the highest frequency of the types of lexical collocations in the textbooks. Meanwhile, there are three differences found regarding the number of lexical collocation frequency in each textbook, the order in using lexical collocations from the highest to the lowest frequency, and the way the authors of the textbooks in introducing and teaching lexical collocations to the students. Furthermore, it was also found that Bahasa Inggris Kelas X produced some inaccurate lexical collocations.
\end{abstract}

Correspondence Address:

Amuntai, Kabupaten Hulu Sungai Utara, 71418, Indonesia

E-mail: nurifadloh@gmail.com 


\section{INTRODUCTION}

Vocabulary still becomes a serious problem for EFL students in Indonesia. Some students show that Indonesian students have lack of vocabulary mastery (Arbayah, 2013; Sari, 2013; Pratiwi et al., 2016; Novianti, 2016; Arifin \& Faridi, 2017; Aristya, 2018; Reskiawan et al., 2020). Further, students also do errors since they are still influenced by their mother tongue (Shweba \& Mujiyanto, 2017). Therefore, vocabulary learning has attracted a lot of attention in teaching of second languages and learning pedagogy. Novianti (2016) stated that the receptive vocabulary scores of second year undergraduate students in an English Education Program in an Indonesian college are lower than 2000 words. It confirms evidences stated by previous researchers (Quinn, 1968; Barnard, 1963 as cited in Read \& Nation, 1986; Abdullah, 2012) that vocabulary knowledge of university students in Asia is still inadequate and demonstrates a low level of vocabulary mastery. Furthermore, the findings of Novianti (2016) are in line with those of Quinn (1968) who confirmed that 'the average university entrant in his sample had a vocabulary of 1000 words after six years of study'. Therefore, it can be stated that Quinn's research findings which were found more than five decades ago are still relevant in this decade. Based on this fact, we can state that there are no significant differences between the undergraduate students' vocabulary mastery in Indonesia since five decades ago. That is why there should be a solution to solve this problem.

Many studies have also been conducted by researchers to improve students' vocabulary mastery (Hajis, 2014; Amri, 2016; Febriansyah, 2016; Mariyana, 2016; Lubis, 2017; Fatimah, 2019; Sainuddin, 2019; Agustina, 2019). The result of the studies showed that the students' ability in mastering vocabulary has been improved. However, those studies were focused on single-word vocabulary. The study related to another point has been relatively neglected by the researchers. Within the field of vocabulary, there is another point which can be regarded as a new theory. It is 'word combinations'.
The study related to 'word combinations' still gets less attention rather than single-word vocabulary. Whereas, it is very common found in language discourses. Conklin and Schmitt (2007) believe that lexical combinations are very common to be found in language discourse and can differentiate the speech of native and nonnative speakers. For example, Howarth (1998), as cited in Anari and Ghaffarof (2013), looks at 238,000 words of academic writing and claims that $31-40 \%$ was composed of collocations and idioms. It proves the statement of Conklin and Schmitt (2007) that word combination forms a large part of any discourses.

Since word combinations are very prominent in language discourse, it needs investigating more deeply. Word combinations which are meant in this case are collocation. Study relating to the collocation has been relatively neglected. As if collocation is not an important part which needs to be observed. In fact, collocation is an important part of English that must be mastered by second or foreign language learners since many native speakers speak English using collocations. Different structures of the words in collocation may produce different meaning, even non-sense meaning in English. That is why learners need to study collocation so that they can speak English as like native speakers.

Everybody knows collocation is very crucial for second or foreign language learners. That is why they should have knowledge to collocate a word with other words to make appropriate or sense meaning. Hill (2003) states that collocations are quite typical of language and could contain as much as $80 \%$ of a written text; thus, they play an essential part of native speakers' competence. It indicates that collocations should be mastered by second or foreign language learners if they want to use their language in a more native-like way. Furthermore, he also suggests that using collocations in listening, speaking, reading or writing in the literature can help learners think more quickly and communicate more efficiently (Hill, 2000).

In this case, students need support to learn collocations. As cited in Englistina et al. (2016), 
Moon (2000) illustrated it in how a woman is helping a child to walk. Through her support, the child is learning to stand upright, to walk and to get strength in his legs. Here, students need a teacher to support them in learning collocations. Teacher will be a guide the students in learning collocations. Further, Pratiwi et al. (2017) suggest that the teachers should encourage the students to develop their vocabularies in English since the EFL students in Indonesia still have difficulty in using and choosing appropriate vocabulary in their language productions. Based on this this role, the teachers should prepare themselves to be ready in guiding students in learning collocations.

Since EFL teachers in Indonesia tend to follow the contents of their textbooks in their teaching, the textbooks play a crucial role in language classroom. It will lead learners to spend so much of class time interacting with the textbooks. Based on those reasons, it is beneficial to look at the use of collocations in language teaching textbooks.

According to Abdelrahman (2004) as cited in Arvianto and Faridi (2016), the textbook is a synonym for curriculum and it is the student's guide which provides him with information and enriches his mind with the knowledge. Further, they add that textbook should provide a plan for learning, a visible outline of what is to be learned in the classroom, as a bank of resource materials and ideas. Based on these statements, the textbook plays an important role in affecting students' ability in mastering the materials.

This study only focuses on mastering lexical collocations since lexical collocations are considered as more difficult collocation to be mastered by the students. The students' ability in acquiring lexical collocation may be affected by the number of lexical collocation encountered. It is caused of multiple encounters that will increase the probability of making a collocation become part of their actual competence (Hill et al., 2000). Many researchers prove that the learners will be helped with numerous exposures especially for the kind of collocations that they have more difficulties with, such as verb-noun lexical collocations (Liu, 2002; Shih \& Wang, 2006). Since textbooks comprise a large part of learners' language input, their encounters with collocations may depend a great deal on textbook content. Therefore, it becomes important to analyse textbook coverage of collocations to know what kind of exposure to lexical collocations students are receiving.

This study attempts to draw the use of lexical collocation in English textbooks used in Indonesia which are written by native speakers and non-native speakers. In this study, the native speakers are represented by Tim Falla and Paul A Davies with their book entitled Aim High Student's Book 1. This book is published by Oxford university press in 2010. This book is used at Senior high school of Semesta Bilingual Boarding School in Semarang, Indonesia. Then, the nonnative speakers are represented by Indonesian writers, named Widiati, Rohmah, and Furaidah with their book entitled Bahasa Inggris Kelas $X$. This book is used at most of senior high schools in Indonesia since it is published by the Indonesian Ministry of Education and Culture in 2014. Furthermore, to cope with the objective, the study investigated the way lexical collocations were presented in the instructions, the course materials, and the exercises in the English textbooks. All of them were investigated to look at whether or not the lexical collocations presented by English textbooks written by native and non-native speakers were balance. These findings can hopefully serve as a reference for the on-going development of new curriculum guidelines for senior high schools by the Indonesian Ministry of Education and Culture.

The concept of collocation was first identified by Palmer (1933) as cited in Nation (2002). He defines collocation as string of words that must or should be learned, or is best or most conveniently learned as an integral whole or independent entity, rather than by the process of piecing together their component parts (Nation, 2002). According to Palmer (1933) as cited in Nation (2002), we need to learn these words on the whole as these words bring single units of meaning, for example: as a matter of fact, at last, and give up to say the least of it. It is because those words may have different meaning even non- 
sense meaning if we use the synonyms of those words. This concept continues from time to time.

Lea (2002) defines collocation as the way words combined in a language to produce natural-sounding speech and writing. For example, in English you say strong wind but heavy rain. It would not be normal to say "heavy wind" or "strong rain". Thus, it takes a greater degree of competence with the language to combine them correctly in productive use. Further, she states that collocation can run from the fairly weak collocation which means the words are easily understood by translating word for word such as "see a film", through the medium strength such as "see a doctor" which means meet a doctor to the stronger collocation as like "see the point" which means understand the point.

This study used two collocation theories proposed by Benson et al. (1997) and Lea (2002). Thus, the collocation classifications used in this study were based on Benson et al. (1997) and Lea (2002). Benson et al. (1997) sort collocations into two categories: lexical collocations and grammatical collocation. A grammatical collocation consists of a dominant word (like a verb, a noun, or an adjective) and a preposition or grammatical structure pattern like a clause or an infinitive (Benson et al., 1997). On the other hand, lexical collocations consist of nouns, adjective, verbs and adverbs. It excludes clauses, infinitive or prepositions (Benson et al., 1997). According to Benson et al. (1997), there are eight major types of grammatical collocations and seven types of lexical collocations.

In addition, Lea (2002) divides collocation into simpler characteristics in each part. According to Lea (2002), grammatically collocations are comprised of a noun followed by a particle, an adjective followed by a particle, a verb followed by a particle, verb followed by verb, and verb followed by adjective. The main element in the grammatical collocation is the specific preposition that occurs after a particular verb, noun or adjective. Then, they are added by two classifications which are verb followed by verb and verb followed by adjective. On the other hand, Lea (2002) also explains that lexical collocations are combinations of words that do not contain grammatical elements, for example: strong tea, do the washing, radio station, a circle of admirers, loudly sneezed, highly prestigious, badly flooded, etc.

Textbooks have a dominant role in the language classroom. Institutional pressures and individual preference influence teachers to follow the textbook faithfully in teaching. It also happens in Indonesia. Almost all of schools use textbooks in teaching their students. According to Yuan and Lin (2001), for EFL teachers who use textbooks with little or no explicit attention given to collocations are advised to compensate for this deficiency. They encourage the teaching of word collocability in addition to single-word vocabulary instruction. Previous empirical studies have shown that direct collocation instruction has positive effects on learners' collocation learning (Chan \& Liou, 2005) and language skill development (Lien, 2003; Hsu, 2002) because it raises learners' awareness of word collocability (Hill et al., 2000; Lewis, 1997). Attention or noticing is essential in all learning. Moreover, it may also provide the additional exposure needed to ensure acquisition of collocations.

\section{METHODS}

In this study, a descriptive qualitative research was employed since the main purpose of the study was to analyze the use of lexical collocations in two textbooks, Aim High Student's Book 1 written by native speakers and Bahasa Inggris Kelas $\mathrm{X}$ written by non-native speakers.

It was assumed that there was difference of using collocations in those textbooks since the authors of those had different knowledge of collocations and language background. Therefore, the difference of collocations will presumably appear in those textbooks. Then, they were analysed as the main data of this research. The importance of collocation itself became a reason why collocation should be introduced and taught to the students at senior high school level.

Then, the object of the study was the collocations presented in the two textbooks, Aim 
High Student's Book 1 and Bahasa Inggris Kelas $\mathrm{X}$. The collocations were analysed based on the classifications of the lexical collocations proposed by Benson et al. (1997) (henceforth LB) and Lea (2002) (henceforth LL). Then, they were compared in terms of the use of collocation in each part of the textbooks: (1) instruction part includes all instructions in the textbooks that order the students to do something; (2) course material part covers all of explanations of the material, reading passages and conversation scripts in the textbooks; and (3) exercise parts consists of all of exercises in the textbooks.

According to Patton (1999), a qualitative research needs to be triangulated in order to make the results of the study ethical and trustworthy. This was triangulated by using theory triangulation. Through this type, two theories regarding collocations proposed by Benson et al. (1997) as LB and Lea (2002) as LL were employed in order to examine and interpret the data. Further, analysts' triangulation was also employed since two supervisors as linguistic experts were involved to re-check and analyze the triangulation of the data in this study.

\section{RESULTS AND DISCUSSIONS}

The comparison between Aim High Student's Book 1 and Bahasa Inggris kelas $X$ in using collocation is very important to be analysed. It is because multiple encounters will increase the probability of making a collocation become part of their actual competence (Hill, Lewis, and Lewis, 2000). The data were collected and classified from the findings as illustrated in Figure 1. This figure showed the lexical collocations found in each part of the two textbooks.

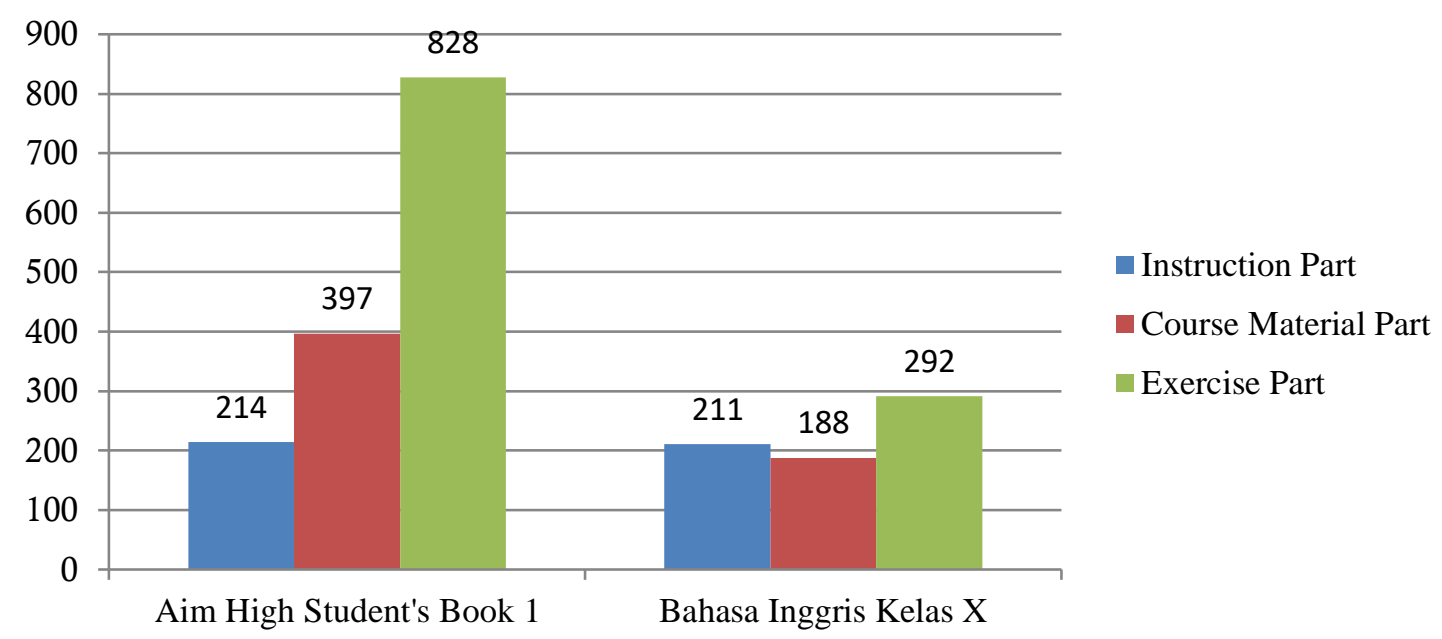

Figure 1: The Numbers of Lexical Collocations between Aim High Studnt's Book 1 and Bahasa Inggris Kelas $X$ in each part of those textbooks

Figure 1 presented the numbers of lexical collocations in each part of the textbooks. Based on the figure above, it can be seen that lexical collocations were found in all parts of the texbooks. However, there was a great difference between Aim High Student's Book 1 and Bahasa Inggris Kelas $X$ in using lexical collocations. The amount of lexical collocations used in Aim Student's Book 1 was 1439 times which consisted of 214 lexical collocations found in instruction part, 397 lexical collocations found in course material part, and 828 lexical collocations found in exercise part. Meanwhile, the amount of collocations used in Bahasa Inggris Kelas $X$ was only 691 times which consisted of 211 lexical collocations found in instruction part, 188 lexical collocations found in course material part, and 292 lexical collocations found in exercise part. Based on the data above, Aim High Student's Book 1 totally used more lexical collocations than Bahasa Inggris Kelas $X$. 
Furthermore, in comparing the use of lexical collocations in both textbooks, there were found some similarities and differences. Those similarities and differences are explained separately in order to make the readers easy to understand this study.

\section{Similarities}

There were three similarities found regarding the lexical collocation occurrence in all parts of the textbooks, the highest frequency of the lexical collocations occurrence in the exercise part of the textbooks, and the highest frequency of the types of lexical collocations in the textbooks.

The first identifiable similarity was the lexical collocation occurrence found in all parts of the textbooks. It reveals that lexical collocations are very important to create texts (Hill, 2000; Lea 2002; Wang and Good 2007; Anari \& Ghaffarof, 2013). It also proves that no piece of natural spoken and written English is totally free of collocation (Lea, 2000).

The second identifiable similarity was the highest frequency of the lexical collocations occurrence in the exercise part of the textbooks. Even though they have different numbers of collocations found in each part of the two textbooks, it can be seen that the highest frequency of collocation occurrence found each exercise part of those textbooks. It indicates that both of them emphasized the introduction and teaching collocations in exercise part.

The last similarity found in this study was the highest frequency of the types of lexical collocations in the textbooks. It could be seen in Table 1.

Table 1. The comparison between Aim High Student's Book 1 and Bahasa Inggris Kelas $X$ in using Types of Collocation Groups

\begin{tabular}{lllll}
\hline Types of & $\mathrm{AH}$ & \multicolumn{3}{l}{$\mathrm{BI}$} \\
\cline { 2 - 5 } LC & $\mathrm{F}$ & $\mathrm{P}$ & $\mathrm{F}$ & $\mathrm{p}$ \\
\hline LL1 & 277 & $19.25 \%$ & 192 & $27.79 \%$ \\
\hline LL2 & 982 & $68.24 \%$ & 368 & $53.26 \%$ \\
\hline LL3 & 8 & $0.56 \%$ & 3 & $0.43 \%$ \\
\hline LL4 & 44 & $3.06 \%$ & 45 & $6.51 \%$ \\
\hline LL5 & 33 & $2.29 \%$ & 27 & $3.91 \%$ \\
\hline
\end{tabular}

\begin{tabular}{lllll}
\hline LL6 & 6 & $0.42 \%$ & 3 & $0.43 \%$ \\
\hline LL7 & 62 & $4.31 \%$ & 20 & $2.89 \%$ \\
\hline LL8 & 19 & $1.32 \%$ & 18 & $2.60 \%$ \\
\hline LB1 & 6 & $0.42 \%$ & 3 & $0.43 \%$ \\
\hline LB2 & 1 & $0.07 \%$ & - & - \\
\hline LB3 & - & - & 2 & $0.29 \%$ \\
\hline LB7 & 1 & $0.07 \%$ & 10 & $1.45 \%$ \\
\hline $\begin{array}{l}\text { Total of } \\
\text { LC }\end{array}$ & 1439 & $100 \%$ & 691 & $100 \%$ \\
\hline $\begin{array}{l}\text { Average } \\
\text { of LC } \\
\text { per } \\
\text { chapter }\end{array}$ & & & & \\
\hline
\end{tabular}

Based Table 1, the data shows that both of Aim High Student's Book 1 and Bahasa Inggris Kelas $X$ provides 11 types of lexical collocations. Among all the types of lexical collocations, LL2 had the highest frequency. LL2 is a type of lexical collocations proposed by Lea (2002) that consists of the combination between verb + noun. This combination became the highest type of collocations used in all parts of the textbooks which indicated that this combination commonly found in language productions. Furthermore, based on the list of dictionary proposed by Benson et al. (1997), LB 1 that consists of the combination between verb + noun also becomes the highest type of lexical collocations proposed by Benson et al. (1997). Therefore, those could be inferred that this type of lexical collocations should be known by the students.

\section{Differences}

There were three differences found regarding the number of lexical collocation frequency in each textbook, the order in using lexical collocations from the highest to the lowest frequency, and the way the authors of the textbooks in introducing and teaching lexical collocations to the students. In addition, it was also found that Bahasa Inggris Kelas $X$ produced some inaccurate lexical collocations while Aim High Student's Book 1 was not.

The first identifiable difference was the number of lexical collocation frequency in each textbook. Based on the findings presented in figure 1, all parts of Aim High Student's Book 
lutilized more lexical collocations than all parts of Bahasa Inggris Kelas $X$. It meant that native speakers were better than non-native speakers in mastering and utilizing lexical collocations. It was caused by they had accustomed themselves to use collocations in their daily life. It as different with non-native speakers who utilized free combinations since they were still influenced their mother tongue in arranging their utterances.

The second identifiable difference was the order in using lexical collocations from the highest to the lowest frequency From the highest to the lowest frequency of collocations, Aim High Student's Book 1 had been ordered this way: (1) exercise part with the amount of 828 lexical collocations; (2) course material part with the amount of 397 lexical collocations; and (3) instruction part with the amount of 214 lexical collocations. Meanwhile, Bahasa Inggris Kelas X from the highest to the lowest frequency of collocations had been ordered this way: (1) exercise part with the amount of 292 lexical collocations; (2) instruction part with the amount of 211 lexical collocations; and (3) course material part with the amount of 188 lexical collocations. Based on these findings, there was an interesting phenomenon in Bahasa Inggris Kelas $X$. Eventhough, the instruction part of this book had fewer portion than course material part, it had more lexical collocations than course material part. It was caused the culture between native speaker and non-native speakers in instructing students using similar words.

The third difference was the way the authors of the textbooks in introducing and teaching lexical collocations to the students. Aim High Student's Book 1 which had ten chapters provided three chapters teaching specific lexical collocations explicitly in specific part of the exercise part. Meanwhile, Bahasa Inggris Kelas X which has fifteen chapters provided six chapters teaching specific collocations explicitly but it did not provide them in specific part of the exercise part. Among ten chapters, Aim High Student's Book 1 has four chapters that teach 29 collocations explicitly in specific part of the exercise part. Meanwhile, among fifteen chapters, Bahasa Inggris Kelas $X$ has six chapters that only teach 9 collocations explicitly without providing the specific part in the exercise part. In sum, Aim High Student's Book 1 has the average of the collocation frequencies which are taught explicitly in each chapter is 2.9 collocations while Bahasa Inggris Kelas $X$ has the average of the collocation frequencies which are taught explicitly in each chapter is 0.6 collocation. Based on the analysis, Bahasa Inggris Kelas $X$ provided too few collocations even it provided less than one collocation in each chapter. It was different with Aim High Student's Book 1 which still provided almost three collocations in each chapter.

The last finding was finding 8 times inaccurate lexical collocations used in Bahasa Inggris Kelas $X$. The inaccurate collocations were found in all parts of the textbook which were instruction part, course material part and exercise part. The word combinations which were inaccurate were such as subjective pronoun, objective pronoun, go the library, and lose or win. It revealed that the non-native authors produced inaccurate collocations in their textbook.

\section{CONCLUSIONS}

This study was conducted in order to compare the two English textbooks used in Indonesia which are written by native speakers, Aim High Student's Book 1 and non-native speakers, Bahasa Inggris Kelas $\mathrm{X}$ in using and teaching lexical collocations. Based on the findings, both of the textbooks utilize lexical collocations in all parts of the textbooks which consist of instruction part, course material part, and exercise part. Furthermore, there were found three similarities in the two textbooks after analyzing the data. They are the lexical collocation occurrence in all parts of the textbooks, the highest frequency of the lexical collocations occurrence in the exercise part of the textbooks, and the highest frequency of the types of lexical collocations in the textbooks. Based on these similarities, we can infer that these two textbooks prove that no piece of natural spoken and written English is totally free of collocation (Lea, 2000). That is why the importance in teaching lexical collocations especially should be 
accentuated in writing textbooks. In addition, there were also found four differences of the two textbooks in using and teaching collocations. They are the number of lexical collocation frequency in each textbook, the order in using lexical collocations from the highest to the lowest frequency, and the way the authors of the textbooks in introducing, teaching lexical collocations to the students and also it was also found that Bahasa Inggris Kelas X produced some inaccurate lexical collocations while Aim High Student's Book 1 was not. Based on these differences, it indicates that the textbook written by native speakers is better than the textbooks written by non-native speakers in utilizing and teaching collocations. Moreover, there were some inaccurate lexical collocations produced by non-native speakers in writing their textbooks. It means that it enables non-native speakers enable to produce inaccurate lexical collocations since collocations are the way words combined in a language to produce natural sounding speech and writing (Lea, 2002). It becomes the reason why the native speakers did not produce inaccurate lexical collocations since they use them in their daily life.

\section{REFERENCES}

Abdullah, N. A. (2012). Notice of retraction quantifying academic readiness: ESL undergraduates' mastery of English vocabulary. 2012 IEEE Symposium on Humanities, Science and Engineering Research, 449-454.

Agustina, N. H. (2019). Using English video songs to improve the seventh grade student vocabulary mastery at Mts Manbail Futuh Tuban. Bachelor's Thesis. Unpublished. Faculty of Education and Teacher Training. UIN Sunan Ampel: Surabaya.

Amri, U. (2016). Increasing students' vocabulary mastery by using Eye-Spy Game at the second grade of SMP Babussalam Selayar. Bachelor's Thesis. Unpublished. Faculty of Education and Teacher Training. UIN Alaudin: Makassar.
Anari, S. M., \& Ghaffarof, S. (2013). The Effect of collocational competence on translating accuracy of translation trainees. Journal of Advances in English Language Teaching, 1 (3), 76-84.

Arbayah. (2013). The Ability of the eleventh grade students of MAN 3 Martapura in listening to short stories Academic Year 2013/2014. Bachelor's Thesis. Unpublished. Faculty of Tarbiyah and Teacher Training. UIN Antasari: Banjarmasin.

Arifin, R. A., \& Faridi, A. (2017). The Students' Perception and Achievement of English Reading Comprehension Using Cognitive Language Learning Strategy. English Education Journal, 7 (2), 139-148.

Aristya, K. (2018). Case study on students' difficulties in vocabulary mastery at SMPN 1 Kebonsari Madiun in Academic Year 2017/2018. Bachelor's Thesis. Unpublished. Tarbiyah Faculty. IAIN Ponorogo: Ponorogo.

Arvianto, Z. I., \& Faridi, A. (2016). The Compatibility of reading exercises with Bloom's revised taxonomy and 2013 Curriculum (A Case of English Textbook Entitled Bahasa Inggris Grade XI Published by Department of National Education 2014). English Education Journal 6 (1), 4252 .

Benson, M., Benson, E., \& Ilson, R. (1997). The BBI Dictionary of English Word Combinations (Rev. ed.). Amsterdam: John Benjamins Publishing Company.

Chan, T., \& Liou, H. (2005). Online verb-noun collocation iinstruction with the support of a Bilingual Concordances. In Selected Papers from the Fourteenth International Symposium and Book Fair on English Teaching, 270-281. Taipei, Taiwan: Crane Publishing Company.

Conklin, K., \& Schmitt, N. (2007). Formulaic sequences: Are they processed more quickly than non-formulaic language by Native and Non-Native Speaker? Applied Linguistics, 28, 1-18.

Englistina, I., Saleh, M., Warsono, \& Rukmini, D. (2016). Developing socio-cultural 
scaffolding model to elicit learners' speech production. The Journal of Educational Development, 4(1), 46-59.

Fatimah. (2019). Improving the students' vocabulary mastery by using picture card at the Eighth Grade of SMP Negeri 9 Parepare. Bachelor's Thesis. Unpublished. Tarbiyah Faculty. IAIN Parepare: Parepare.

Febriansyah, I. (2016). Improving students' vocabulary mastery through Bingo Game at Grade X of SMAN Purworejo in the Academic Year of 2014-2015. Bachelor's Thesis. Unpublished. Faculty of Language and Arts. Universitas Negeri Yogyakarta: Yogyakarta.

Hajis, A. R. (2014). Improving Students' Vocabulary by Using Visual Media at SMP Negeri 10 Makassar. Bachelor's Thesis. Unpublished. Faculty of Teacher Training and Education. UIN Alaudin: Makassar.

Hill, J. (2000). Revising Priorities: From Grammatical Failure to Collocational Success. In Lewis, M. (Ed.), Teaching Collocation: Further Developments in the Lexical Approach, 47-69. Hove, England: Language Teaching Publications.

Hill, J. (2003). The Place of Collocation in the Syllabus. Selected Papers from the Twelfth International Symposium on English Teaching, 81-86. Taipei, Taiwan: Crane Publishing Company.

Hill, J., Lewis, M., \& Lewis, M. (2000). Classroom Strategies, Activities and Exercises. In Lewis, M. (Ed.), Teaching Collocation: Further Developments in the Lexical Approach, 88-117. Hove, England: Language Teaching Publications.

Hsu, J. (2002). Development of collocational proficiency in a workshop on English for General Business Purposes for Taiwanese College Students. Doctoral Dissertation. Unpublised. Indiana University of Pennsylvania, Pennsylvania.

Lea, D. (2002). Oxford Collocations Dictionary for Students of English. Oxford: Oxford University Press.
Lewis, M. (1997). Implementing the Lexical Approach: Putting Theory into Practice. London: Language Teaching Publications.

Lien, H. (2003). The Effects of collocation instruction on the reading comprehension of Taiwan College Students. Doctoral Dissertation. Unpublised. Indiana University of Pennsylvania. Pennsylvania.

Liu, A. L. (2002). A Corpus-based Lexical Semantic Investigation of Verb-Noun Miscollocations in Taiwan learners' English. Master's Thesis. Unpublished. Tamkang University. Taipei, Taiwan.

Lubis, I. R. (2017). Improving students' vocabulary mastery by using Fly Swatter Game in the First Grade of MTs Persatuan Amal Bakti (PAB) 1 Helvetia. Bachelor's Thesis. Unpublished. Faculty of Tarbiyah and Teacher Training. UIN Sumatera Utara: Medan.

Mariyana, D. E. (2016). The vocabulary mastery of the fifth grade students of SDN 1 Tumpangkrasak in Academic Year 2015/2016 taught by using Word Clap Game. Bachelor's Thesis. Unpublished. Faculty of Teacher Training and Education. Universitas Muria Kudus: Kudus.

Nation, I. S. P. (2002). Learning Vocabulary in Another Language ( $3^{\text {rd }}$ ed.). Cambridge: Cambridge University Press.

Novianti, R. (2016). A study of Indonesian university students' vocabulary mastery with vocabulary level test. Global Journal of Foreign Language Teaching, 6(4), 187-195.

Patton, M. Q. (1999). Enhancing the quality and credibility of qualitative analysis. Health and Services Research Journal, $34(5 \mathrm{Pt} 2)$, 1189-1208.

Pratiwi, Y. E., Rukmini, D., \& Faridi, A. (2017). The linguistic problems of students' competence in Writing Business Letters. Language Circle: Journal of Language and Literature, 9(2), 117-126.

Quinn, K. (1968). Virgil's Aeneid; a critical description. University of Michigan Press. 
Read, J., \& Nation, P. (1986). Some issues in the testing of vocabulary knowledge. ERIC.

Reskiawan, B., Andas, N. H., \& Hajra. (2020). A Study on students' difficulties In vocabulary mastery at First Grade Students of SMPN 1 Baula. Tamadun Life Jurnal Bahasa, Sastra dan Budaya 19(1), 3454.

Sainuddin, A. A. (2019). Improving students' vocabulary mastery through vocabulary Self-Collection Strategy (VSS) at Dormitory of Sate Islamic Institute (IAIN) Parepare. Bachelor's Thesis. Unpublished. Tarbiyah Faculty. IAIN Parepare: Parepare.

Sari, H. (2013). Junior high school students' mastery in translating English descriptive text into Indonesian. Bachelor's Thesis. Unpublished. Faculty of Tarbiyah and Teacher Training. UIN Antasari: Banjarmasin.

Shih, S., \& Wang, H. (2006). The Relationship between EFL learners' depth of vocabulary knowledge and oral collocation errors. In The 23 International Conference on English Teaching and Learning in the Republic of China, 964-977. Taipei, Taiwan: Kaun Tang International Publishing Ltd.

Shweba, A. A. A., \& Mujiyanto, Y. (2017). Errors or spelling, capitalization, and punctuation marks in writing encountered by first year college students in Al-Merghib University Libya. English Education Journal, 7(2), 92-102.

Wang, J. T., \& Robert L. G. (2007). The repetition of collocations in EFL rextbooks: A Corpus Study. In the $16^{\text {th }}$ International Symposium and Book DAIRY on English Teaching. Taipei, Taiwan: Kaun Tang International Publishing Ltd.

Yuan, H., \& Lin, C. (2001). Collocations: A Case study of Ming Chuan University Student. In Proceedings of the Eighteenth Conference on English Teaching and Learning in the Republic of China, 407-420. Taipei, Taiwan: Crane Publishing Company. 